\title{
MÍDIA AUTÓCTONE E INCLUSIVA EM PERIFERIAS URBANASE [SUB]URBANAS: ALGUM AS CONSIDERAÇÕES ACERCA DE PESQUISAS EM COMUNICAÇÃO COMUNITÁRIA
}

\author{
Ricardo Olivaira de Freitas ${ }^{1}$
}

Resumo: Considerando o fenômeno de visibilização de iniciativas de comunicação popular e comunitária, o texto ora apresentado aborda os métodos e as técnicas utilizadas na pesquisa acerca dos processos de comunicação e das interações sociais destes resultantes, a partir do lugar ocupado pelas mídias audiovisuais (vídeo, TV comunitária e cinema de rua) para o desempenho das identidades minoritárias e suas expressões no Brasil. Para tanto, analisa a reincidência de produções que tomam o debate sobre o minoritário e periférico como tema central, constituindo o campo das mídias radicais alternativas, com base nos novos movimentos e nas ações que têm encontrado na mídia (grande mídia e mídias radicais alternativas) importante suporte para desenvolvimento de novas expressões e alianças político-sociais entre democracia, terceiro setor, sociedade civil e grupos ideologicamente minoritários - elaborando, assim, novos modos de representação contra-hegemônicos, com a promoção de políticas públicas e/ou culturais para a inclusão social. Investiga, portanto, a apropriação e utilização de recursos de mídia audiovisuais por grupos e comunidades ideologicamente minoritários, no almejo de alcançarem reconhecimento junto à esfera de visibilidade pública e, por extensão, à esfera pública política, a partir da análise e da elaboração de uma cartografia das iniciativas de comunicação popular e comunitária desenvolvidas na periferia de Salvador.

Palavras-Chave: Cultura de minorias, Representações, Mídias alternativas, Comunicação e movimentos sociais, Comunicação popular.

Abstract: This paper aims to analyze processes of communication and social interactions as a result of the emergency of popular and communitarian communication. It analyzes also the recurrence of productions that refers to the debate about minorities as central subject, constituting the field of the radical alternative media. It investigates therefore the appropriation and use of the technologies of media by minority communities which try to achieve recognition by the sphere of public visibility and, therefore, the political public sphere, based on the analysis and the development of a cartography of popular and communitarian communication initiatives developed on the poor areas of Salvador.

Keywords: Minorities culture, Representations, Alternative media, Communication and social movements, Popular communication.

1 Professor Titular da Universidade do Estado da Bahia (UNEB), Campus I, Salvador; Docente do Programa de Pós-Graduação em Crítica Cultural da UNEB, Campus II, Alagoinhas. Endereço eletrônico: ricofrei@gmail.com. 


\section{COM UNICAÇÃO COM UNITÁRIA É COMUNICAÇÃO AUTÓCTONE}

0 texto ora apresentado é resultante da pesquisa por mim coordenada, que considera o fenômeno da emergência de iniciativas de comunicação popular e comunitária a fim de refletir sobre a positividade dos processos de comunicação e das interações sociais resultantes destas inciativas. Reflete, ainda, sobre a importância das mídias audiovisuais para o desempenho das identidades minoritárias e suas expressões no Brasil. Serve como aliado da divulgação dos métodos e das técnicas utilizadas na pesquisa, além de delimitar o tema e a sua importância para a criação de inciativas em mídia cada vez mais inclusivas. A pesquisa analisa a reincidência de produções que tomam o debate sobre o minoritário e periférico como tema central, seja apropriando-se de recursos da grande mídia, seja utilizando recursos próprios das mídias radicais alternativas. Investiga, portanto, a apropriação e utilização de recursos de mídia audiovisuais por grupos e comunidades ideologicamente minoritários, no almejo de alcançarem reconhecimento junto à esfera de visibilidade pública e, por extensão, à esfera pública política, a partir da análise e da elaboração de uma cartografia das iniciativas de comunicação popular e comunitária desenvolvidas na Bahia (num primeiro momento, no Extremo Sul do Estado e, atualmente, em periferias de Salvador).

As práticas de comunicação popular e comunitária estão estritamente relacionadas à necessidade de implantação de um modelo justo de sociedade, que contemple a inserção de grupos e comunidades (até então) desprestigiados junto às esferas de poder, privilégio e prestígio. Tais práticas se propõem a contribuir para a positivação das representações acerca de grupos e comunidades juridicamente vulneráveis, por conta de uma eficaz política de representação em mídia, que, quando não exclui, apresenta negativando a participação de grupos e comunidades indesejadas, através de representações pejorativas, deturpadas e desqualificantes. Por isso, pensar a comunicação comunitária é pensar sobre as formas de fortalecimento da democracia, com base na positivação de expressivo segmento da população brasileira junto à esfera de visibilidade pública e, por extensão, à esfera pública política. Com isso, reconheço que a comunicação comunitária também está relacionada à projeção e à visibilidade em meios de comunicação, que, nesse sentido, chegam mesmo a traduzir a ideia de esfera pública constituída. É como se reconhecêssemos um mundo regido pela

126 Número temático: M etodologias de pesquisa em ciências sociais e humanas. A Cor das Letras 
comunicação e seus meios, que tem nos veículos mecânicos e tecnológicos de comunicação e informação a representação maior da ideia de esfera pública, que passa, nesse momento, a dizer respeito não apenas aos espaços físicos, concretos e objetivos, de exercício das ações de coletividade, mas, também, aos espaços virtuais, nem por isso menos públicos.

Muitos são os autores que defendem a ideia de que, ao deixar de constituírem-se em instrumentos de mediação social para configurarem-se em instrumentos de midiatização, os meios de comunicação de massa transformaram fenômenos sociais em espetáculos (DEBORD, 2003). A tônica da espetacularização não proporcionou anseio por visibilidade enquanto fenômeno de grandiosidade e beleza, pura e simplesmente. Espetacularização, aqui, traduz-se pela lógica do ineditismo e da representação embutida na ideia de espetáculo. Nesse sentido, grupos e comunidades até então invisibilizadas nos projetos midiáticos, ao almejarem inclusão e reconhecimento junto à esfera de visibilidade pública (que podemos mesmo traduzir como a esfera de visibilidade midiática), anseiam mais que a exposição infundada de suas iniciativas. Anseiam, pois, pela aquisição de reconhecimento de seus problemas, prioridades e, sobretudo, de seus modos de vida e visões de mundo junto às esferas de poder. Por isso, as iniciativas de comunicação comunitária tentam encontrar formas de interação (de comunicar) entre comunidades - quer seja entre grupos e comunidades afins, quer seja entre grupos e comunidades desinteressadas e junto à sociedade abrangente e hegemônica. Também por isso, comunicação comunitária passa a traduzir a ideia de pertencimento de grupos e comunidades ideologicamente minoritárias junto à esfera hegemônica, relacionando, pois, comunicação comunitária, cultura de minorias, mídias alternativas, midiativismo e ações de resistência.

É no gancho da invisibilidade que surgem duas novas ondas no panorama da produção midiática brasileira. Dizem respeito ao movimento de [1] tomar a voz e [2] dar voz aos invisibilizados, excluídos e marginalizados, através de recursos midiáticos - tanto em [1] mídias alternativas como na [2] grande mídia.

Para o caso [1] das mídias alternativas, surge no bojo dos movimentos e ações que encontram nos recursos midiáticos importantes suportes para desenvolvimento de novas expressões e alianças político-sociais entre Estado, governo, democracia, terceiro setor, sociedade civil e grupos ideologicamente minoritários. Elaboram, assim, novos modos de representação contra-hegemônicos, que chamam a atenção para a promoção de políticas 
públicas a fim de contribuir para a inclusão social e para a redução da desigualdade social através de recursos de comunicação popular.

Para o caso [2] da grande mídia, é sobre novas formas de produção artística e cultural como ações inclusivas e sobre a utilização de novas tecnologias na alternativa indústria cultural [periférica] que tal tipo de produção tem se debruçado - elaborando algo em torno do conceito de "redenção pela arte e tecnologia".

Nesse sentido, refiro-me, especificamente, à produção de audiovisual realizada nos últimos dez anos, quase sempre, por produtores não periféri$\cos$ (e, por isso, centrais) de fora para dentro ou de fora para fora.

0 interesse sobre tal tipo de temática não surge por acaso. É resultado do histórico processo sociopolítico brasileiro, num período configurado pela abertura política e pela determinação de implantar um projeto de democratização das nações periféricas, às raias de ingressarem, de fato, na modernidade pós-ditatorial. A popularização dos movimentos sociais, desmantelando 0 alijamento das classes populares das decisões políticas e 0 debate sobre cidadania, desigualdade e inclusão social, permite-nos assistir à cooperação entre sociedade civil organizada (com suas representações societárias, movimentos sociais e populares), Estado, governo e incontáveis organizações mediadoras (ONGs). Tal articulação e toda a sorte de parceria e negociação entre tais esferas realçam a necessidade de estabelecimento de políticas públicas e de representação identificatória, que consolidam 0 diálogo direto entre poder público e sociedade civil. A expressividade de redes de solidariedade, organizadas entre sociedade civil e terceiro setor, faz emergir, através dos recursos de mídia, vozes subalternizadas e invisibilizadas, excluídas dos projetos de cidadanização e do processo civilizatório brasileiro, através de "atores coletivos cívicos - associações voluntárias, movimentos sociais, porta-vozes de causas" (M AIA, 2006).

Martin-Barbero (2004) chama a atenção para o fato de que as alternativas de comunicação popular não devem, necessariamente, ser marginais às grandes mídias. Podem mesmo apoderar-se de traços de cultura massiva. 0 que não é problema. Entretanto, devem atentar para o fato de que as culturas populares não são homogêneas - tal qual o discurso construído pela grande mídia. 0 problema reside no fato de que no que é produzida para massificação e controle das massas, a cultura massiva tende a negar as diferenças, fazendo com que desapareçam por assimilação e, com isso, homogeneizando-as. 
Considerando que mesmo o gosto popular está moldado pela cultura de massa, reconhecemos que a comunicação será alternativa ao assumir a complexidade dos processos de massificação da cultura (e formação da comunicação massiva) que são estruturados na quase negação do popular. Digo, quase, já que entendo que numa análise aguçada dos complexos processos de formação da cultura massiva, podemos perceber traços de popularidade, "de códigos e dispositivos em que se imbricam a memória popular e 0 imaginário das massas" (M ARTIN-BARBERO, 2004, p. 213).

É, pois, necessário tecer uma visão aguçada sobre a totalidade das estruturas de produção da informação. Para Martin-Barbero, é nos interstícios das "estruturas transnacionais da informação e estruturas nacionais do poder" que são revelados domínios ideológicos em modos de ver, que não dizem respeito apenas aos espectadores, mas também aos produtores. Estes últimos, também videntes, espectadores.

Os modos de ver são produzidos socialmente, pelo imaginário coletivo. Por isso, a análise do produto não deve centrar-se exclusivamente no produto em si e na sua condição de reproduzir a verdade, mas nos dispositivos de enunciação-produção, de percepção e reconhecimento. Ou seja, os estudos das tecnologias ou dos meios devem ceder lugar aos estudos debruçados sobre a produção de mensagens situadas no âmbito da cultura, a partir de um prisma que privilegie a interação das mídias na mediação entre indivíduos (produtores, receptores e produtores-receptores) na esfera da cultura e sociedade contra uma ideologia tecnocrática, que permeia e esteriliza os esforços da comunicação alternativa, da informação contrahegemônica, já que não chega a questionar verdadeiramente as estruturas ideológicas e políticas da produção de informação (cf. MARTIN-BARBERO, 2004).

Sigo, aqui, a trilha traçada por Jesus M artin-Barbero, ao reconhecer que os estudos de comunicação não devem, necessariamente, recair sobre as suas especificidades técnicas, mas sobre o lugar em que a comunicação reside no campo da cultura. Dessa forma, entendemos que, "a comunicação se tornou para nós questão de mediações mais que de meios, questão de cultura e, portanto não só de reconhecimento, mas re-conhecimento". Mediações seriam as "articulações entre práticas de comunicação e movimentos sociais para as temporalidades e para a pluralidade de matrizes culturais", que permitem compreender a "natureza comunicativa" do sujeito, esfera em que as noções de cultura e política são redefinidas, saindo da centralidade da esfera que avalia apenas a "mera circulação de informa- 
ções" dos meios comunicacionais - na qual o receptor é apenas "decodificador daquilo que o emissor depositou na mensagem" - e partindo para 0 ponto em que ele reveste-se de mero decodificador à "produtor" (M ARTINBARBERO, 1997, p. 19).

0 resgate dos modos de réplica do dominado desloca o processo de decodificação do campo da comunicação, com seus canais, seus meios, suas mensagens, para o campo da cultura, ou melhor, dos conflitos entre a cultura e a hegemonia. Aceitar isso é também algo completamente diferente de 'relativizar o poder das mídias'. 0 problema de fundo coloca-se agora em outro nível: já não no nível das mídias, mas sim dos mediadores e dos modelos culturais (M ARTIN-BARBERO, 2004, p.127).

Através da promoção de políticas midiáticas elaboradas ou defendidas pelos grupos, até então, excluídos do projeto midiático brasileiro, emerge um movimento de produção audiovisual, que terá como principal característica a valorização de aspectos socioculturais inerentes à realidade desses grupos (minoritários, periféricos e invisibilizados). Essa é a ideia de mídia-ação, mediação. Como são tanto personagens como protagonistas, transformam-se de invisibilizados em visibilizados, de excluídos em incluídos, de minorias em maiorias, de desprivilegiados em privilegiados, de passivos espectadores em ativos produtores, criando uma espécie de ativismo social midiático, midiativismo, através da geração de meios próprios e específicos elaborados pelos grupos ou comunidades interessadas, baseados em formas de associações alternativas que têm privilegiado a produção e participação em mídia como cenário para a elaboração de novos ativismos sociais e, por extensão, para a organização de redes sociais contemporâneas.

A reflexão sobre a concentração e controle da mídia e a circulação e distribuição massiva da informação versus um modelo de comunicação midiática, que privilegia problemáticas locais, regionais, anti-hegemônicas e alternativas, impõem outro debate. A forma com que a mídia brasileira contribui para a construção de um imaginário e de uma realidade excludente, que diz respeito à reformulação do espaço público das minorias brasileiras e da positivação de sua real inserção no processo civilizatório brasileiro e na demarcação de seu espaço na esfera do exercício de cidadania.

Portanto, pensar a partir de territórios periféricos (próximos e distantes) permite-nos refletir sobre o conceito de periferia da periferia - contribuindo, assim, para o debate sobre cidadanização, que extrapola, pois, a 
esfera da teoria da comunicação e engrossa os estudos sobre sociedade e cultura.

\section{ALGUMAS CONSIDERAÇÕES A PARTIR DO CASO DA BAHIA}

Com base nas questões acima apresentadas, criei, em janeiro de 2007, o Grupo de Estudos e Pesquisa em Mídias Alternativas e M idiativismo (GUPEM A), que tem como finalidade agregar projetos de pesquisa e extensão desenvolvidos por professores e alunos de graduação e pós-graduação. Os projetos têm como objeto central questões referentes ao universo da comunicação popular e comunitária. 0 grupo concentra pesquisas que visam refletir sobre políticas de inclusão junto à esfera pública política por grupos e comunidades minoritárias e pelos movimentos sociais distanciados das esferas de poder, privilégio e prestígio, em distintas regiões do Estado da Bahia. 0 Grupo está dividido em quatro linhas de pesquisa, que são: Estudos Culturais; Etnografia da Comunicação; Mídia, Cultura de Minorias e M ovimentos Sociais; Mídia, Identidade e Representações.

0 universo de interesse do Grupo e dos projetos agregados versa sobre a mídia (mais especificamente, audiovisual) e suas contribuições para a consolidação de um [novo] mercado midiático, que, a partir de uma tendência mundial, tenta referenciar identidades pessoais, locais, regionais e étnicas em oposição à premissa da singularização unificada e ímpar trazida no bojo do debate sobre globalização. Dessa forma, nossas atividades se encaixam no rol de produções preocupadas com o paradoxo entre o global e o local, tradição e modernidade, que tem constituído, nos últimos tempos, as discussões nas ciências sociais e em estudos de cultura e mídia.

Como objetivos específicos, o Grupo (com o projeto vigente) apresenta as seguintes questões: Contribuir para as discussões em torno das políticas de identificação e cidadanização (e, por extensão, da nacionalidade) como temas emergentes dos veículos e discursos comunicativos, culturais e mediadores, a partir do debate sobre identidade e diferença que tem, tão incisivamente, tomado tônica nos últimos tempos com o advento da globalização, além de fornecer elementos para uma análise crítica da produção videotelevisiva brasileira, em seus aspectos comercial, social e comunicacional. Reconhecer a importância da comunicação popular para a construção de redes de solidariedade, acenando para a sua paradoxal configuração, que cria formas de socialização que se estabelecem no âmbito do público (as audiências de TV e cinemas de rua estabelecem relação com 0 outro em espaços que são públicos, a céu aberto), na contramão da ideia 
onipresente de que as novas tecnologias de comunicação contribuem para consolidar a privatização das relações sociais contemporâneas ao serem acessíveis em âmbito privados. Analisar o papel da comunicação popular e comunitária como recurso para preservação e fomentação do panorama cultural de microrregiões e comunidades destituídas de poder, caracterizando-se não somente como importante recurso para registro e preservação da memória tradicional local, como também, possibilitando acesso a novas tecnologias e a novas formas de produção cultural e inaugurando novos modos de organização social. Divulgar novos modos de comportamento presentes em microrregiões e na realidade de microgrupos (ou em qualquer prática cotidiana sob a égide da globalização), não se restringindo, apenas, à preservação de traços tradicionais isolados, mas de traços tradicionais articulados com formas, modos e estilo-de-vida propostos pela modernidade, a partir do lugar em que a comunicação popular funciona como prática social contemporânea. Avaliar a importância da comunicação popular e comunitária para a formação técnica e para o aperfeiçoamento profissional de integrantes de microrregiões nordestinas, criando novas linhas de emprego e renda. Analisar os mecanismos que cooperam para o apaziguamento de ações excludentes, redução da desigualdade social e fomento da inclusão social, visando elevar os índices de melhoria da qualidade de vida e desenvolvimento humano junto a populações destituídas de reconhecimento, fomentando a participação inclusiva e cidadã (inserção junto à esfera pública política e à esfera de visibilidade pública) através de recursos de mídia. Por fim, avaliar a participação dos grupos e comunidades minoritárias para a elaboração de uma contrainformação que reelabora o que é produzido sobre si mesmas.

\section{A COM UNICAÇÃO QUE INCLUI}

Através da transformação de símbolos eminente locais, particulares e singulares em símbolos nacionais, coletivos, após a década de 1950 (com a difusão da indústria televisiva e publicitária no Brasil), viu-se consolidar um modelo de identidade hegemônico, que excluía elementos culturais minoritários e que bastante contribuiria para a definição de um modelo de identidade "unívoca" entre brasileiros (tanto integrantes de classes dominantes como populares). Grupos desprivilegiados não deixaram de ser contemplados. Porém foram caracterizados sob papéis que, mesmo quando fugiam aos clichês e estereótipos tão bem estruturados, não correspondiam à rea-

132 Número temático: M etodologias de pesquisa em ciências sociais e humanas. A Cor das Letras 
lidade dessas populações no Brasil - esse, o caso de nordestinos, afrodescendentes, homossexuais, populações sub-urbanas e periféricas etc. A mídia, nesse sentido, contribuiu para a consolidação de um projeto em mão única, que pouca atenção deu à participação de certos segmentos populacionais no processo civilizatório brasileiro, fazendo, assim, de um país diverso e plural, um país unívoco, hegemônico, outro de si mesmo.

0 fato é que a emissão e recepção da informação, reduzida à lógica univocal (emissor, mensagem e receptor) foi desmantelada no momento em que redes (e a cibernética tem importante papel) de solidariedade permitiriam um debate eficazmente mais participativo, no qual a lógica "emissor, mensagem, receptor" se caracterizaria pela conferência (até mesmo on-line), lugar de vários mundos culturais, estilos e formas de vida, por isso, espaços plurivocais, onde emissor, receptor e mensagem são agentes comuns e não mais meros receptores daquilo que o emissor (proprietário da informação e empresa) depositou na mensagem (Cf. MARTIN-BARBERO, 1997). Essa é a característica mais marcante das mídias radicais alternativas: todos são produtores da informação: receptores, audiências e/ ou consumidores são também emissores da mensagem. Isso comprova a idéia de que as (novas) redes são espaços que desmantelam características gerais da comunicação clássica, reduzidas à lógica do emissor e receptor como sujeitos distintos. Surge, assim, um campo de prática mais aberto, mais participativo e melhor distribuído, certo tipo de comunicação em rede de solidariedade (Cf. LÉVY, 1993).

Tal fato também chama a atenção para a necessidade de se tecer uma análise crítica da mídia brasileira (e de velhos e novos produtos audiovisuais), em seus aspectos comerciais, sociais e comunicacionais, considerando as lógicas de homogeneização e heterogeneidade dos produtos midiáticos, o que nos remete às questões de reterritorialização e desterritorialização da produção e recepção.

Com base no acima exposto, analisei iniciativas de produção audiovisual realizadas por movimentos sociais na periferia de Salvador, que tinham apoio de agências internacionais e parcerias com entidades governamentais e não governamentais (ONGs), caracterizando-se como iniciativas de fomento em projetos de e para inclusão social. Levei em consideração o distanciamento representacional e simbólico dos bairros e comunidades frente às esferas de poder, privilégio e prestígio.

0 recorte sobre as TVs e cineclubes comunitários deteve-se sobre as instituições promotoras e seus compromissos com a fomentação de ins- 
trumentalização (oferta de oficinas) em mídia - sobretudo, a produção de vídeos e toda a sorte de produtos audiovisuais, mesmo em situações em que o sistema de transmissão não se encontrava definitivamente instalado. Para o caso das localidades onde o sistema de transmissão não se encontrava instalado, me concentrei, pois, na produção e na exibição do material audiovisual, mesmo quando utilizando recursos domésticos para exibição e transmissão - como telão, VCR e DVD (TV e cinema de rua). Ainda: a escoIha das organizações da sociedade civil ou organizações não governamentais (ONGs) considerou o respaldo e reconhecimento de tais instituiç̧ões junto às comunidades de origem e a preocupação com a utilização de recursos audiovisuais como instrumentos para a elaboração de ações inclusivas. Além disso, as organizações tinham em comum 0 alto índice de públicos jovens como audiência principal.

Ressalvo, ainda, que o recorte sobre os produtos analisados levou em consideração a variedade de gêneros e formatos e, paradoxalmente, a homogeneidade de repertórios entre tais produtos; cidadania e inclusão social.

0 universo da pesquisa ora apresentada dividiu-se em duas esferas. Uma primeira, dizia respeito à pesquisa do produto. Outra, à pesquisa da recepção. Ambas, tentaram dar conta do interesse central do projeto, que foi: avaliar a importância da produção de audiovisual para a construção de um modelo de identidade, num primeiro momento, segmentada, depois, regional e, por fim, nacional, atentando para a importância de tais produtos para a elaboração de modelos identificatórios entre grupos minoritários no Brasil. Interessou-me perceber as peculiaridades tanto nas formas de produção como nas formas de recepção entre os conjuntos de produtos videotelevisivos, quando retratam realidades objetivas e subjetivas dos grupos contemplados.

A especificação das diversas representações (pejorativas ou favoráveis) de grupos minoritários na produção midiática nacional (grande mídia) em comparação à representação de tais grupos na produção das mídias alternativas contribuiu, assim, para o debate sobre cidadanização, que extrapola, pois, a esfera da teoria da comunicação e engrossa os estudos sobre sociedade e cultura. Para tanto, a investigação e problematização do contexto histórico das mídias e produtos aqui contemplados foi outro método utilizado (método histórico).

Através de método comparativo, buscou-se refletir sobre as formas com que essas representações são tanto produzidas (e ofertadas) como 134 Número temático: M etodologias de pesquisa em ciências sociais e humanas. A Cor das Letras 
recebidas (e assimiladas). A análise da recepção foi de grande valia, já que reconheço que o que, aqui, chamamos colonialidade cognitiva (FREITAS e TAVARES, 2010), reflete tanto o processo de criação dos produtos como a aceitação (ou recusa) das mensagens recebidas. Com isso, não me interessei em tecer um estudo das tecnologias ou dos meios, mas da produção de mensagens situadas no âmbito da cultura, a partir de um prisma que privilegiasse a interação das mídias na mediação entre indivíduos (produtores, receptores e produtores/receptores) na esfera da cultura e sociedade. Essa a ideia de mídia-ação, mediação, que considera a mídia como prática social. Levou-se em conta a contribuição que tais produtos e suas representações deram para a idealização e concretização de práticas excludentes (xenófobas, discriminatórias, racistas etc.) e/ ou inclusivas.

Os procedimentos adotados foram: [1] Gravação, observação e análise dos produtos selecionados a fim de identificar regularidades e anomalias, através de decupagem de material selecionado, considerando os traços midiográficos mais relevantes para o foco de interesse nas sequências selecionadas. 0 número de sequencias a selecionar foi determinado de acordo com 0 andamento e, por extensão, o interesse da pesquisa no decorrer do processo de investigação. 0 tracejo da mensagem discursiva, permitiu-me perceber os elos entre produção e reconhecimento, a partir da lógica das mediações dos recortes das minorias aqui vislumbradas. [2] Pesquisa exploratória e coleta de dados a partir de trabalho-de-campo, isto é, participação na produção dos produtos audiovisuais (com frequência aos cursos de instrumentalização e produção, sobretudo), a fim de identificar elementos que privilegiassem preocupação para com questões de políticas inclusivas. [3] Análise da recepção que contemplou não o produto, mas o sujeito pesquisado, possibilitando o entendimento de que a ideia de uma TV geralista não encontra respaldo em meio à diversidade cultural brasileira.

Acreditando que é na interseção entre mídia e cultura que reside a construção e experimentação do produto audiovisual, reconhecer a especificidade de audiências diferenciadas foi fundamentalmente importante para perceber de que forma as audiências que me interessavam elaboravam significados e sentidos no campo da recepção do produto comunicacional. Tais significados e sentidos podiam mesmo decidir a formulação de novos gêneros e formatos audiovisuais, fazendo vislumbrar o lugar em que residem recepção e produção como coisas combinadas. Esse, o caso da emergência das mídias radicais alternativas e seus produtos. 
Tal fato, me remeteu às seguintes questões: qual a participação da mídia (grande mídia e mídias radicais alternativas) para a elaboração de alteridade entre grupos minoritários brasileiros; qual o espaço reservado pela mídia para o debate exclusão e desigualdade social, políticas compensatórias e construção de cidadania para populações excluídas; qual a contribuição da mídia para o retardamento ou aceleração de um projeto de democracia no Brasil; num momento regido sob a égide da globalização, qual o perigo da singularização (da unificação-ímpar) num processo político, econômico, cultural e social que se revela pluralizado (com a promoção das multiplicidades, da diversidade); a partir da crença de que os meios de comunicação contribuem tanto para a destituição das identidades particulares como para a promoção de identidades estereotipadas, qual a contribuição da mídia audiovisual para a exclusão das identidades não contempladas por esses meios; como os meios de comunicação pensam e refletem as mudanças políticas e socioculturais no Brasil que colocam as classes populares dentro dos mais diversos papéis e que vão consolidar um modelo de representação de um Brasil moderno; quais as diferentes representações do povo brasileiro nessas mídias; qual o lugar reservado à caracterização de tipos identitários na mídia brasileira?

Vale ressalvar que tais questões não são o mote exclusivo para elaboração dos problemas de interesse do Grupo e da pesquisa, já que dizem respeito a considerações universais, genéricas. Contudo, podem ser pensadas a partir da realidade do objeto aqui analisado.

Acredito que num momento em que tanto se tem falado em políticas compensatórias, devemos reavaliar o lugar destinado à participação de determinados segmentos sociais no estabelecimento de ações democráticas no Brasil. Considero que a pesquisa ora apresentada firmou-se na proposta de contribuir para a formulação de políticas sociais, considerando 0 espaço acadêmico (a Universidade) como potencial gerador de conhecimentos aplicáveis à sociedade abrangente (à sociedade civil). Reconheço, também, o importante papel que os meios de comunicação de massa, mais especificamente, a TV, ocuparam para a dinamização das representações sociais que caracterizam as sociedades e as culturas ocidentais modernas este, 0 caso do Brasil e da região Nordeste. Considero, ainda, que tanto a Universidade quanto os meios e tecnologias de comunicação são importantes domínios para a eficácia das mediaç̃oes sociais.

Num momento em que, no Brasil, o debate em torno das políticas de ações afirmativas vem tomando tônica, evidencia-se, pois, a necessidade de 136 Número temático: M etodologias de pesquisa em ciências sociais e humanas. A Cor das Letras 
suscitar a investigação sobre as representações das minorias para o caso brasileiro. Afinal, tais representações foram formuladas sob a égide de uma dita democracia social, que esteve única e estritamente relacionada ao debate sobre nação e identidade nacional (não tendo sido, portanto, particularizadas). E foi, sobretudo, através de expressiva produção acadêmica e em meios de comunicação de massa, que o debate sobre nacionalismos (e, por extensão, todo tipo de recortes identitários) se evidenciou.

Com base no acima exposto, espero, pois, contribuir para o debate sobre cultura e mídia como temas emergentes na produção do conhecimento e nas discussões acerca de iniciativas inclusivas de comunicação.

\section{REFERÊNCIAS}

APPADURAI, Arjun. Disjunção e diferença na economia cultural global. In: FEATHERSTONE, Mike. (Org.). Cultura global. Petrópolis: Vozes, 1994, p. 311-28.

BHABHA, Homi K. A questão do "outro": diferença, discriminação e o discurso do colonialismo. In: HOLANDA, Heloisa B. (Org.). Pós-modernismo e política. Rio de Janeiro: Rocco, 1991, p. 177-203.

CANCLNI, Nestor G. Consumidores e cidadãos: conflitos multiculturais da globalização. Rio de Janeiro: Ed. UFRJ, 1997.

CANCLNI, Nestor G. Culturas híbridas. São Paulo: EDUSP. 1997a.

DEBORD, Guy. A sociedade do espetáculo. Rio de Janeiro: Contraponto, 2003.

DOWNING, John. Mídia radical: rebeldia nas comunicações e movimentos sociais. São Paulo: Ed. SENAC. 2002.

FREITAS, Ricardo O. de; TAVARES, Julio C. S. Mídia e racismo: colonialidade e resquícios do colonialismo. In: GOMBERG, E.; MANDARINO, A. (Org.). Racismos: olhares plurais. Salvador: EDUFBA, 2010, v. 1, p. 205-222.

GRAM SCl, Antonio. Os intelectuais e a organização da cultura. São Paulo: Círculo do Livro. 1982.

GUIMARÃES, César; FRANÇA, Vera. (Org.). Na mídia, nas ruas: narrativas do cotidiano. Belo Horizonte: Autêntica, 2006.

JAMBEIRO, Othon et al. Comunicação, hegemonia e contra-hegemonia. Salvador: EDUFBA, 2005.

LÉVY, Pierre. As tecnologias da inteligência. São Paulo: Ed. 34, 1993.

LIMA, Venício. Prefácio. In: Id. Vozes da democracia: histórias da comunicação na redemocratização do Brasil. São Paulo: Intervozes/Imprensa Oficial, 2006.

MAIA, Rosiley; CASTRO, Maria Ceres. (Org.). Mídia esfera pública e identidades coletivas. Belo Horizonte: Ed. UFM G. 2006.

MARTIN-BARBERO, Jesus. Dos meios às mediações: comunicação, cultura e hegemonia. Rio de Janeiro: Ed. UFRJ. 1997. 
M ARTIN-BARBERO, Jesus. Ofício de cartógrafo. São Paulo: Loyola, 2004.

PAIVA, Raquel. 0 espírito comum. Rio de Janeiro: Mauad, 2002.

PAIVA, Raquel; BARBALHO, Alexandre. Comunicação e cultura das minorias. São Paulo: Paulus, 2005.

SANTOS, Boaventura de Sousa. Pela mão de Alice: o social e o político na pós-modernidade. 5. ed. São Paulo: Cortez, 1999. 